\title{
Anti-cartilage antibody
}

\author{
C. L. GREENBURY AND J. SKINGLE \\ From the Pathology Laboratory, Stoke Mandeville Hospital, Aylesbury, Bucks, UK
}

SUMMARY Antibody to cartilage has been demonstrated by indirect immunofluorescence on rat trachea in the serum of about $3 \%$ of 1126 patients with rheumatoid arthritis. Titres ranged from 1:20 to $1: 640$. The antibody was not found in 284 patients with primary or secondary osteoarthritis or in 1825 blood donors, nor, with the exception of two weak reactors, in 1314 paraplegic patients. In most cases the antibody appears to be specific for native type II collagen. Using this as an antigen in a haemagglutination test $94 \%$ of anti-cartilage sera were positive, whereas among 100 rheumatoid control sera there were only three weak positives. More than $80 \%$ of patients with antibody had some erosion of articular cartilage, but there was no correlation with age, sex, duration of disease, nor any recognisable clinical event or change.

Reports of anti-cartilage antibody in human sera are uncommon and have been limited to a few cases of relapsing polychondritis (Hughes et al., 1972; Rogers et al., 1973).

In the course of a survey of anti-tissue antibodies by immunofluorescence on rat tissues we found a serum which reacted strongly with a piece of tracheal cartilage accidentally included in one of the blocks. Since this occurrence in 1975, tracheal and costal cartilage have been included routinely in the tissue blocks, and we have found more than $\mathbf{4 0}$ patients with anti-cartilage antibody, most of whom had rheumatoid arthritis.

This paper describes the antibody, its probable identity with anti-type II collagen, and its incidence among 5000 patients and blood donors.

\section{Material and methods}

SOURCES OF SERA

\section{Blood donors}

1825 sera were kindly supplied by the Oxford BTS, who also provided details of the age and sex (but not the names) of donors.

\section{Patients of the National Spinal Injuries Centre} Inpatients were tested once a month and outpatients at each six-monthly attendance. 1314 patients were tested on an average of $2 \cdot 3$ occasions.

Received for publication 23 January 1979

\section{Patients of the Oxford Regional Rheumatic Diseases Research Centre}

Inpatients were tested once a month and outpatients usually at each attendance. 1785 patients were tested on an average of 3.0 occasions.

TEST FOR ANTI-TISSUE ANTIBODIES

Sera were tested by indirect immunofluorescence (IF) on cryostat sections of unfixed rat tissues. Rat tissues were assembled into two composite blocks: (i) kidney, liver, sciatic nerve, and stomach, (ii) costal cartilage, heart muscle, intercostal muscle, oesophagus, spinal cord, submaxillary gland, thyroid, and trachea.

Fluorescein-conjugated sheep anti-human sera: anti-immunoglobulin, anti-IgG, anti-IgM, anti-IgA and anti- $\mathrm{C}_{3}$ were obtained from Wellcome Reagents Ltd. Sera to be tested were screened at a dilution of $1: 10$ using the anti-immunoglobulin. The immunoglobulin class of any antibody present was then determined and titrated with the specific immunoglobulin antisera.

SHEEP CELL AGGLUTINATION TEST (SCAT) Sera to be tested were diluted in $2.5 \%$ sheep serum (Greenbury, 1960).

\section{LATEX A G GLUTINATION}

Slide tests were performed at a single serum dilution (1:20) using a suspension of latex particles (BactoLatex 0.81 ) mixed with human Cohn fraction II previously heated to $60^{\circ} \mathrm{C}$ for 2 minutes. 
HAEMAGGLUTINATION TEST (HA) FOR

ANTIBODIES TO TYPE II COLLAGEN

Formolised sheep red blood cells were tanned with 1:40 000 tannic acid and then sensitised with human native type II collagen at the optimum dilution determined on the day of test. The collagen was derived from the nucleus pulposus of the intervertebral disc and was prepared and kindly supplied by Dr Helen Beard (Charles Salt Research Centre, Oswestry). Sera were absorbed with unsensitised cells before being titrated in microtitre trays.

\section{Results}

\section{IMMUNOFLUORESCENCE}

In rat tracheal cartilage the commonest pattern was fluorescence at the periphery of the cartilage only (Fig. 1b), although some of the strongest sera produced fluorescence throughout the matrix (Fig. 1a). If the sections were pre-treated with hyaluronidase all anti-cartilage sera produced a degree of generalised fluorescence. In costal cartilage fluorescence occurred throughout the matrix even with the weaker sera; pre-treatment with hyaluronidase enhanced the fluorescence but did not alter its distribution.

All positive sera reacted with human tracheal and articular cartilage. A small number of positive sera were tested with pig trachea, fowl trachea, and rat pinna; all reacted. Immunofluorescence titres varied from $1: 20$ to $1: 640$ with a mode of $1: 40$; the antibody
Table 1 Incidence of anti-cartilage antibody

\begin{tabular}{lccc}
\hline Diagnosis & $\begin{array}{l}\text { No. of } \\
\text { individuals }\end{array}$ & \multicolumn{2}{l}{ Positive } \\
\cline { 3 - 4 } & & No. & $\%$ \\
\hline Rheumatoid arthritis & 1126 & 37 & $3 \cdot 3$ \\
Psoriatic arthropathy & 67 & 1 & $1 \cdot 5$ \\
Primary generalised osteoarthritis & 97 & 0 & - \\
Secondary osteoarthritis & 187 & 0 & - \\
Ankylosing spondylitis & 183 & 0 & - \\
Polymyalgia rheumatica & 99 & 0 & - \\
Gout & 26 & 0 & - \\
Paraplegia & 1314 & 2 & $0 \cdot 2$ \\
Blood donors & 1825 & 0 & - \\
\hline
\end{tabular}

was exclusively IgG and did not react with anti-IgM or IgA. There was no fixation of complement $\left(\mathrm{C}_{3}\right)$.

OCCURRENCE OF ANTI-CARTILAGE ANTIBODY Anti-cartilage antibody was found in 40 patients, all but two of whom had rheumatoid arthritis or psoriatic arthropathy, an incidence of about $3 \%$ (see Table 1). The two non-rheumatoid patients with anticartilage antibody were from among 1314 paraplegics; they gave only weak but repeated positive reactions. In addition, there were 21 doubtful positives, that is, patients from whom a single serum, either one of a series or the only serum tested, gave a weak anti-cartilage reaction. At least 14 of these patients were suffering from rheumatoid arthritis or psoriatic arthropathy. No cartilage positive serum was found among blood donors or patients with locomotor disease other than rheumatoid arthritis, including 284 patients with osteoarthritis.
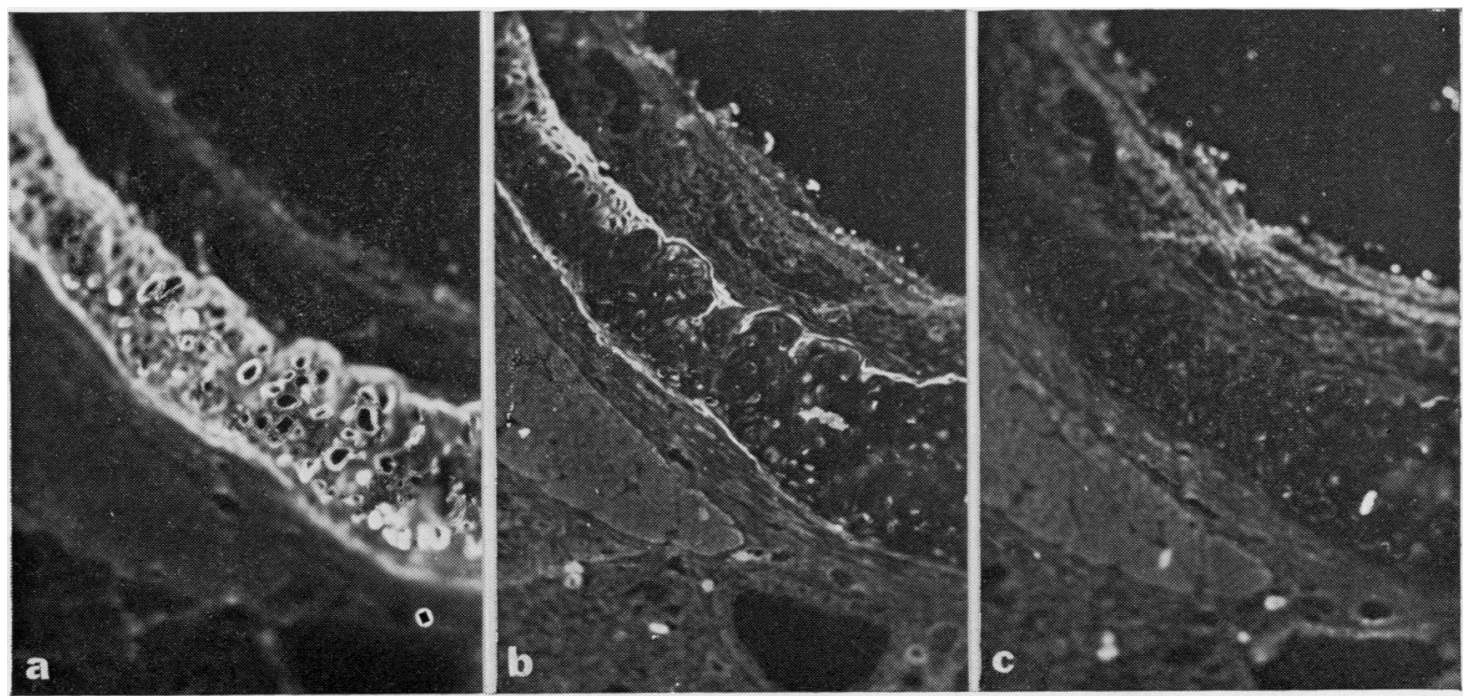

Fig. 1 Patterns of immunofluorescence in rat tracheal cartilage ( $\times 100):$ (a) generalised; (b) peripheral; (c) negative control. 
The 40 patients with anti-cartilage antibody are detailed in Table 2 . The only finding positively correlated with anti-cartilage antibody was the presence of articular erosions (x-ray grades 3 and 4), which were. or had been, present in $25(78 \%)$ of the 32 patients on whom data were available. The actual incidence of erosions probably exceeded $78 \%$, since the current practice is, after initial x-rays of hands and feet, to take no further radiographs except perhaps at three-year intervals, unless surgical intervention is contemplated.
The presence of anti-cartilage antibody was not related to age, sex, or duration of disease. The exact relationship with duration of disease could not be determined since 32 of the patients were positive on first testing, when in many cases the disease had been present for some years. The mean age of patients with anti-cartilage antibody was, however, the same as that of the whole population of rheumatoid patients attending the Rheumatic Research Centre. Antibodies to other tissues were often present with anti-cartilage, but none occurred with any greater

Table 2 Patients with anti-cartilage antibody

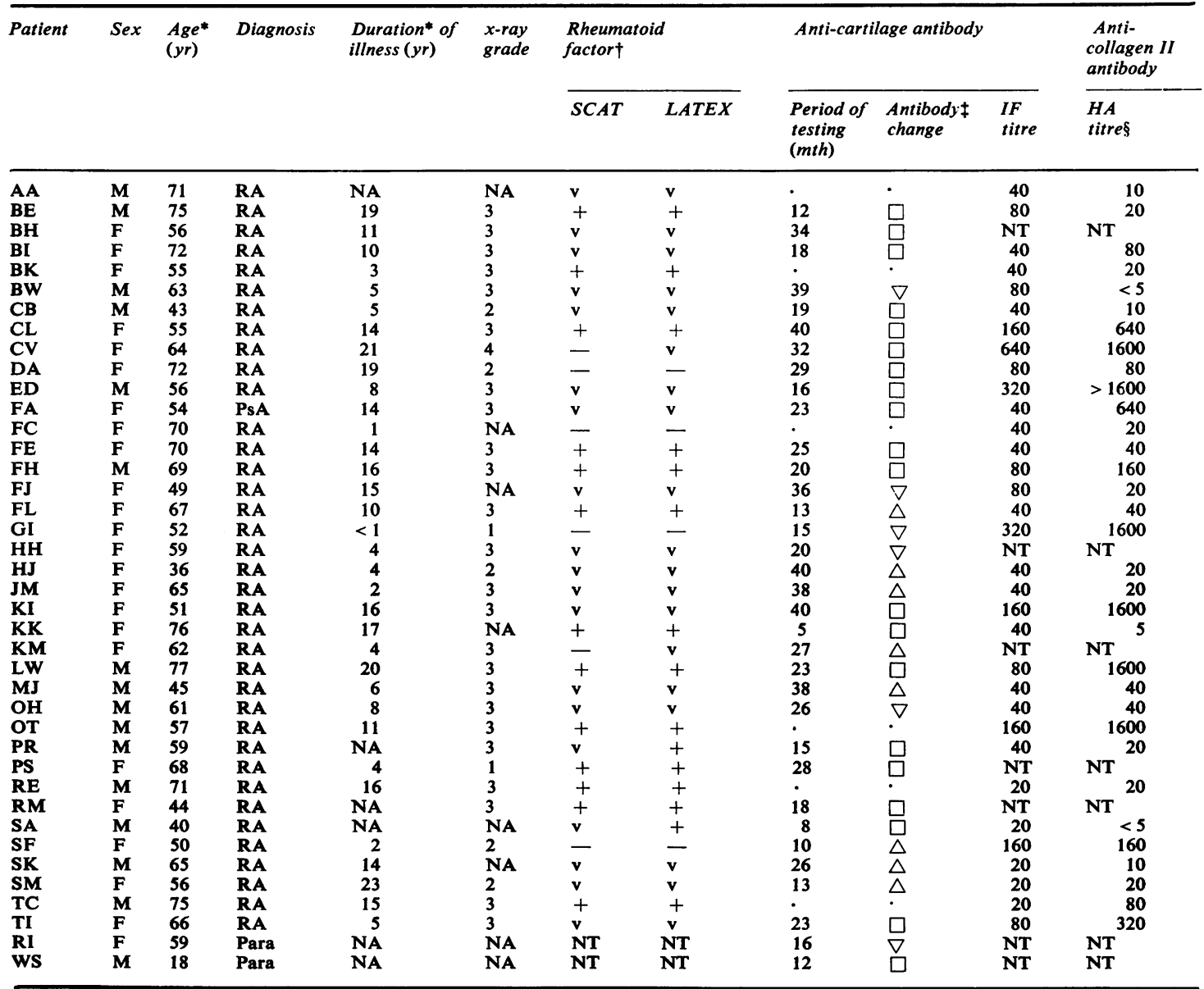

RA = rheumatoid arthritis (4/5 ARA criteria); PsA = psoriatic arthropathy; Para = paraplegia.

*When cartilage antibody first detected.

NA = information not available.

†Rheumatoid serology for the entire period of surveillance:

+ always positive $\mathbf{v}$ variable

- always negative NT not tested

$\ddagger$ Direction of antibody change during period of testing:

$\nabla$ positive to negative $\square$ always positive

$\triangle$ negative to positive patient tested once only

§The serum with the highest IF titre from each patient was used for the IF:HA comparison. 
frequency than in the generality of patients with rheumatoid arthritis.

There is some suggestion of a correlation between anti-cartilage antibody and positive rheumatoid serology. Table 2 (cols 7 and 8 ) shows patients' serology for the whole period of their attendance at Stoke Mandeville Hospital, which in many cases extends well before 1975 when anti-cartilage testing was begun. Thirty-three $(89 \%)$ of the 37 patients with rheumatoid arthritis in Table 2 were seropositive, that is, they have had positive tests for rheumatoid factor at some stage in their disease. Three of the four seronegative patients had rheumatoid arthritis of only short duration, and, statistically speaking, at least one of them is likely to become seropositive. This would result in an overall seropositivity rate of $92 \%$ for anti-cartilage positive patients, which contrasts with an overall rate of $82 \%$ for the 960 patients with rheumatoid arthritis whose serology we have followed for at least three years (unpublished data).

Most patients in Table 2 were tested for tissue antibodies on a number of occasions. In the majority, anti-cartilage antibody was present at the first test and persisted throughout the period of surveillance. In some the antibody appeared for the first time while the patient was under observation, and in others the antibody initially present disappeared; both groups of patients tended to be those whose disease was of shorter duration. In no case was it possible to link the appearance of the antibody with any clinical event.

SPECIFICITY OF ANTI-CARTILAGE ANTIBODY Since no antibody to any other tissue present in the blocks regularly accompanied anti-cartilage antibody, it seemed probable that the latter owed its specificity to some constituent peculiar to cartilage-either proteoglycan or type II collagen (Miller, 1973). Absorption with proteoglycan derived from pig cartilage (kindly supplied by Dr Helen Muir, FRS, The Kennedy Institute of Rheumatology, London) failed to remove or to diminish the anti-cartilage titre in a serum shown to react with pig cartilage. Accordingly, sera from two patients were sent to Dr Helen Beard to be tested against type II collagen. Absorption on a column containing insolubilised type II collagen removed the antibody; and both HA and IF activity were subsequently recovered by elution.

After this demonstration in two sera of the close association, if not identity, of anti-cartilage with anti-type II collagen, we tested 33 IF positive sera by haemagglutination using cells coated with native type II collagen: 31 were positive in titres of $1: 5$ to $1: 1600$, average 1:80. Table 2 shows that there was an obvious though not exact correlation between the HA and IF titres, although two of the IF positive sera were HA negative.

As virtually all our anti-cartilage sera were from cases of rheumatoid arthritis, 100 random anticartilage negative RA sera were tested by $\mathrm{HA}$ as controls. Among these 100 sera there were only five weak positives with titres from $1: 2$ to $1: 10$. These were retested by immunofluorescence for anticartilage antibody; the two strongest (HA titre 1:10) were found to be IF positive at a titre of $1: 5$ (that is, below the dilution at which sera were originally screened).

\section{Discussion}

Our findings seem to be of some interest because they concern an autoantibody to a tissue directly involved in a disease generally thought to be of autoimmune origin. The antibody hitherto regarded as rare is certainly very limited in its distribution and is practically confined to patients with rheumatoid arthritis.

The evidence points strongly to the anti-cartilage antibody here described being closely related to, if not identical with, antibody to native type II collagen, the distribution of which in the body is almost entirely confined to cartilage and intervertebral disc (Eyre and Muir, 1975, 1976; Miller, 1973). However, the two antibodies are not identical in every case, since two of the patients with anti-cartilage antibody had negative HA tests for anti-collagen type II; moreover, the titres of anti-cartilage correlate only roughly with those of anti-collagen type II. There is thus some heterogeneity within the anti-cartilage sera, possibly in the specificity for different antigenic sites on the collagen molecule; there are also variations in patterns of fluorescence with tracheal cartilage. These heterogeneities and the more detailed specificities of the antibodies are being further investigated.

There have been a number of reports of anti-collagen antibodies in rheumatoid arthritis.These mostly concern native or denatured type I collagen: in serum (Adam et al., 1977; Michaeli and Fudenberg, 1974); in synovial fluids (Cracchiolo et al., 1975; Menzel et al., 1976); or antigen-antibody complexes in synovial fluid cells (Steffen et al., 1974). One group of workers, however, have found antibody to type II collagen in synovial fluids (Mestecky and Miller, 1975) and in serum in both the IgG and IgM fractions (Andriopoulos et al., 1976a, b, c). It is only with the last group that we can compare our findings, and we find great difficulty in reconciling our results with theirs. These authors found a high incidence (in the range $60-75 \%$ ) of antibodies to both 
native and denatured collagens of types I, II, and III compared with $3-4 \%$ of anti-cartilage and anti-type II collagen in our series. It is unlikely that this wide discepancy is due to a simple difference in sensitivity of the methods used, since the two tests described here gave results in close agreement, yet differed widely in both substrate and method. A more probable explanation could lie in differences in the antigen used, or perhaps in some fibronectin- or rheumatoid factor-like substance present in rheumatoid arthritis which has been responsible for haemagglutination in the Birmingham, Alabama, series.

Collagen, especially type II, would fit so admirably the part of antigen in a self-perpetuating autoimmune arthritis that it is not surprising that those who have found anti-collagen antibodies should attribute to them a causative role in the aetiology of rheumatoid arthritis (Steffen, 1970). Indeed, it has been shown experimentally that immunisation with type II collagen can produce arthritis in rats (Trentham et al., 1977). We can offer no evidence on this topic, but the low incidence of anti-cartilage antibody suggests that it is unlikely to be a prime aetiological factor. No doubt anti-cartilage antibody is present at some time in the disease more often than we have found it here, since we have seen it sometimes to be only fleetingly present, or to disappear after being well established; even so, our results suggest that it is unlikely to occur at all in more than a small minority of patients. This argument against a causative role for anti-cartilage antibody would have less force if the serum antibody were, as very well may be the case, only an 'overflow' of that produced in the synovial tissues. We have not found anticartilage antibody in the few rheumatoid synovial fluids examined, but the fluids were not pre-treated with collagenase or hyaluronidase. The high correlation of anti-cartilage antibody with erosions is no better evidence for it being a cause rather than a consequence of cartilage damage. It is nonetheless interesting to speculate why antibody to cartilage is not found in osteoarthritis which involves extensive damage to cartilage.

The figures are too small for any statistical comment on psoriatic arthropathy, but it is worth noting that the single patient with anti-cartilage antibody and psoriasis was seropositive and therefore may more properly belong in the group in which rheumatoid arthritis and psoriasis are coincidental.

In addition to those mentioned in the text we thank Dr A. G. S. Hill (Director of The Regional Rheumatic Diseases Centre) for clinical information and permission to publish some work which is an offshoot of a joint study on rheumatoid serology, $\mathrm{Dr}$ D. J. Vernon (National Spinal Injuries Centre) for supplying us with samples of blood from routine bleeding of paraplegic patients, and Dr A. J. Bailey (Meat Research Institute, Bristol) for some preliminary work confirming the anti-collagen II nature of some of our sera.

\section{References}

Adam, M., Bozděch, V., Musilová, J., and Deyl, Z. (1977). Rheumatoid arthritis and collagen antibodies. Scandinavian Journal of Rheumatology, 6, 186-188.

Andriopoulos, N. A., Mestecky, J., Miller, E. J., and Bennett, J. C. (1976a). Antibodies to human native and denatured collagens in synovial fluids of patients with rheumatoid arthritis. Clinical Immunology and Immunopathology, 6, 209-212.

Andriopoulos, N. A., Mestecky, J., Miller, E. J., and Bradley, E. L. (1976b). Antibodies to native and denatured collagens in sera of patients with rheumatoid arthritis. Arthritis and Rheumatism, 19, 613-617.

Andriopoulos, N. A., Mestecky, J., Wright, G. P., and Miller, E. J. (1976c). Characterization of antibodies to the native human collagens and to their component $\alpha$ chains in the sera and the joint fluids of patients with rheumatoid arthritis. Immunochemistry, 13, 709-712.

Cracchiolo, A., III, Michaeli, D., Goldberg, L. S., and Fudenberg, H. H. (1975). The occurrence of antibodies to collagen in synovial fluids. Clinical Immunology and Immunopathology, 3, 567-574.

Eyre, D. R., and Muir, H. (1975). The distribution of different molecular species of collagen in fibrous, elastic and hyaline cartilages of the pig. Biochemical Journal, 151, 595-602.

Eyre, D. R., and Muir, H. (1976). Types I and II collagens in intervertebral disc. Biochemical Journal, 157, 267-270.

Greenbury, C. L. (1960). A comparison of the RoseWaaler, latex fixation, "RA-TEST" and Bentonite Flocculation tests. Journal of Clinical Pathology, 13, 325-330.

Hughes, R. A. C., Berry, C. L., Seifert, M., and Lessof, M. H. (1972). Relapsing polychondritis: Three cases with a clinico-pathological study and literature review. Quarterly Journal of Medicine, 41, 363-380.

Menzel, J., Steffen, C., Kolarz, G., Eberl, R., Frank, O., and Thumb, N. (1976). Demonstration of antibodies to collagen and of collagen-anticollagen immune complexes in rheumatoid arthritis synovial fluids. Annals of Rheumatic Diseases, 35, 446-450.

Mestecky, J., and Miller, E. J. (1975). Presence of antibodies specific to cartilage-type collagen in rheumatoid synovial tissue. Clinical and Experimental Immunology, 22, 453-456.

Michaeli, D., and Fudenberg, H. H. (1974). The incidence and antigenic specificity of antibodies against denatured human collagen in rheumatoid arthritis. Clinical Immunology and Immunopathology, 2, 153-159.

Miller, E. J. (1973). A Review of biochemical studies on the genetically distinct collagens of the skeletal system. Clinical Orthopaedics and Related Research, 92, 260-280. 
Rogers, P. H., Boden, G., and Tourtellotte, C. D. (1973). Relapsing polychondritis with insulin resistance and antibodies to cartilage. American Journal of Medicine, 55, 243-248.

Steffen, C. (1970). Consideration of pathogenesis of rheumatoid arthritis as collagen autoimmunity. Zeitschrift für Immunitätsforschung, Allergie und klinische Immunologie, 139, 219-227.

Steffen, C., Ludwig, H., and Knapp, W. (1974). Collagenanticollagen immune complexes in rheumatoid arthritis synovial fluid cells. Zeitschrift für Immunitäts- forschung, experimentelle und klinische Immunologie, 147, 229-235.

Trentham, D. E., Townes, A. S., and Kang, A. H. (1977). Autoimmunity to type II collagen: an experimental model of arthritis. Journal of Experimental Medicine, 146, 857-868.

Requests for reprints to: Dr C. L. Greenbury, Pathology Laboratory, Stoke Mandeville Hospital, Aylesbury, Bucks HP21 8AL, UK.

\section{The July 1979 Issue}

\section{THE JULY 1979 ISSUE CONTAINS THE FOLLOWING PAPERS}

Plasma lipoproteins, lipid transport, and atherosclerosis: Recent developments N. E. MILLER

A new chromogenic assay for the specific determination of prothrombin J. L. FRANCIS

An improved method for the measurement of red cell survival using non-radioactive chromium $\mathrm{H}$. C. DRYSDALE, P. M. EMERSON, AND A. HOLMES

Bone marrow culture in aplastic anaemia A. J. BARRETT, A. FAILle, N. BALITRAND, F. KETELS, AND Y. NAJEAN

Erythroid progenitors (BFU-e and CFU-e) in acute leukaemia A. URABE, M. J. MURPHY, JR, M. HAGHBIN, AND T. S. GEE

A study of nuclear diameters in lymph node imprints using the Zeiss Microvideomat J. CROCKER AND R. C. CURRAN

Malignant lymphoma with a high content of epithelioid histiocytes DOROTHY HAYES AND J. H. ROBERTSON

A renal biopsy study in toxaemia of pregnancy C. R. TRIBE, G. E. SMART, D. R. DAVIES, AND J. C. MACKENZIE

Human endodermal sinus tumour in nude mice and its markers for diagnosis and management T. TAKEUCHI, M. NAKAYASU, S. HIROHASHI, T. KAMEYA, M. KANEKO, K. YOKOMORI, AND Y. TSUCHIDA

Comparison of electron microscopy, enzyme-linked immunosorbent assay, solid-phase radioimmunoassay, and indirect immunofluorescence for detection of human rotavirus antigen in faeces CHRISTOPHER J. BIRCH, NOREEN I. LEHMANN, ALISON J. HAWKER, JOHN A. MARSHALL, AND IAN D. GUST
Alpha-1-antitrypsin Pi S phenotype and liver cell inclusion bodies in alcoholic hepatitis J. K. KELLY, T. V. TAYLOR, AND A. MILFORD-WARD

A radioimmunoassay for hepatitis $\mathbf{A}$ antigen and antibody S. J. SKIDMORE AND E. H. BOXALL

Biochemical identification of clinically important yeasts JOHN DE LOUVOIS, ANNE MULHALL, AND ROSALINDE HURLEY

Tablet sensitivity testing of pathogenic fungi J. B. CASALS

Characteristics of Pseudomonas aeruginosa in relation to laboratory-induced resistance to gentamicin G. DIMITRACOPOULOS, C. INTZES, AND J. PAPAVASSILIOU

Effect of tobacco and nicotine on growth of Haemophilus influenzae in vitro DAVID-ROBERTS AND PETER COLE

Handwashing and antiseptic-containing soaps in hospital J. D. JARVIS, C. D. WYNNE, L. ENWRIGHT, AND J. D. WILLIAMS

\section{Technical method}

An evaluation of Intralactam, a preparation for the detection of $\beta$-lactamase production by Haemophilus influenzae D. B. WHELDON AND MARY P. E. SLACK

Letters to the Editor

Book reviews

Uniform requirements for manuscripts submitted to biomedical journals

Copies are still available and may be obtained from the PUBLISHING MANAGER, BRITISH MEDICAL ASSOCIATION, TAVISTOCK SQUARE, LONDON WC1H $9 \mathrm{JR}$, price $£ 3 \cdot 00$, including postage 